\title{
Correlates of body fat and waist circumference in children from São Caetano do Sul, Brazil
}

\author{
Correlatos da gordura corporal e circunferência da cintura \\ em crianças de São Caetano do Sul, Brasil
}

Gerson Luis de Moraes Ferrari (https://orcid.org/0000-0003-3177-6576) 1,2

Dirceu Solé (https://orcid.org/0000-0002-3579-0861) ${ }^{2}$

Carlos Pires (https://orcid.org/0000-0001-9190-1119) ${ }^{3}$

Victor Matsudo (https://orcid.org/0000-0003-3552-486X) ${ }^{4}$

Peter T. Katzmarzyk (https://orcid.org/0000-0002-9280-6022) ${ }^{5}$

Mauro Fisberg (https://orcid.org/0000-0003-2992-3215) ${ }^{2}$

\footnotetext{
${ }^{1}$ Centro de Investigación en Fisiologia del EjercidoCIFE, Universidad Mayor. José Toribio Medina 29.

Estacion Central Santiago Chile. gersonferrari08@ yahoo.com.br

${ }^{2}$ Disciplina de Alergia, Imunologia Clínica e Reumatologia do Departamento de Pediatria, Universidade Federal de São Paulo. São Paulo SP Brasil.

${ }^{3}$ Centro de Matemática da Universidade de Trás-os-

Montes e Alto Douro (CMUTAD). Vila Real Portugal.

${ }^{4}$ Centro de Estudos do Laboratório de Aptidão Física de São Caetano do Sul (CELAFISCS). São Caetano do Sul SP Brasil.

${ }^{5}$ Pennington Biomedical Research Center. Baton Rouge Louisiana United States.
}

\begin{abstract}
The purpose of this study was to examine potential correlates of body fat (BF) and waist circumference (WC) in children. The sample included 328 children (169 boys) aged 9-11 years. $B F(\%)$ was measured using a bioelectrical impedance scale. WC measurements were made on exposed skin at the end of a normal expiration using a non-elastic anthropometric tape. Moderate-to-vigorous physical activity (MVPA) and sedentary behavior were measured using accelerometers. Participants with complete individual, family and home, and school environmental data were included in the analysis. Children averaged $21.3 \%$ in boys and $25.8 \%$ in girls for BF and 68.0 $\mathrm{cm}$ in boys and $67.2 \mathrm{~cm}$ in girls for WC. There was higher BF among girls ( $p<0.001)$, but no significant sex differences with respect to WC. In boys, breakfast consumption, bad sleep quality, and MVPA were associated with BF. Among girls, the only variables associated with $B F$ were breakfast consumption and bad sleep quantity. Bad sleep quality and MVPA were associated with WC in boys. Among girls, WC was associated with breakfast consumption and bad sleep quantity. We identified correlates of $B F$ and WC in children; however, few correlates were common for both $B F$ and WC, and for both boys and girls.
\end{abstract}

Keywords Body fat, Waist circumference, Child.
Resumo O objetivo deste estudo foi examinar os potencias correlatos da gordura corporal (GC) $e$ da circunferência da cintura (CC) em crianças. A amostra incluiu 328 crianças (169 meninos) de 9-11 anos. A GC (\%) foi avaliada usando a bioimpedância elétrica e a CC $(\mathrm{cm})$ usando uma fita antropométrica não elástica. A atividade física de moderada à vigorosa (AFMV) e o tempo sedentário (TS) foram mensurados usando acelerômetros. Os participantes que tinham informações completas individuais, familiares, e de ambiente da moradia e escolar foram incluídos nas análises. As médias das crianças foram $21,3 \%$ nos meninos e $25,8 \%$ nas meninas para $G C$ e $68,0 \mathrm{~cm}$ nos meninos e 67,2 cm nas meninas para CC. A média das meninas foi maior do que nos meninos para GC $(p<0.001)$. Não encontramos diferença significativa entre os sexos para CC. Nos meninos, o consumo de café da manhã, qualidade de sono ruim e AFMV foram associados com GC. Nas meninas, as únicas variáveis associadas foram o consumo do café da manhã e qualidade de sono ruim. Qualidade de sono ruim e AFMV foram associadas com CC nos meninos. Nas meninas, CC foi associada significativamente com consumo de café da manhã e qualidade do sono ruim. Identificamos correlatos da GC e da CC em crianças, no entanto, poucos correlatos foram comuns para GC e CC e em ambos os sexos.

Palavras-chave Tecido adiposo, Circunferência da cintura, Crianças. 


\section{Introduction}

Obesity is an important lifestyle-related public health problem worldwide'. The prevalence of obesity in children has risen significantly during the past few decades not only in high-income countries but also in low- and middle-income countries $^{2}$. One recent review has reported that the prevalence of childhood overweight and obesity rose by $47.1 \%$ between 1980 and 2013 worldwide ${ }^{3}$.

The association between obesity, defined by various assessment methods, and comorbidities/ mortality is considered to be strong and causal ${ }^{4}$. Even though body fat (BF) is associated with an increased health risk, abdominal fat mass has proved to be an independent risk factor for the development of comorbidities such as stroke, type II diabetes, hypertension, and cancer ${ }^{4}$. In adults, markers of central BF distribution are associated with visceral fat and components of the metabolic syndrome ${ }^{5}$. Waist circumference (WC) is also associated with cardiovascular disease risk factors in children ${ }^{6}$.

The prevalence of overweight and obesity among Brazilian children may have increased during the last decades leading to concern among public health authorities. In 2010, the National School of Health (Pesquisa Nacional de Saúde do Escolar) reported that $33.5 \%$ of Brazilian children were overweight, and $16.6 \%$ of boys and $11.8 \%$ of girls were obese ${ }^{7}$. Strategies implemented to reduce overweight/obesity in children, especially at the school level, have reported inconclusive outcomes - some showed significant results ${ }^{8}$, while others $\operatorname{did~not~}^{9}$. A better understanding of lifestyle characteristics associated with obesity is needed to reduce the negative behavioural and health effects of excessive weight in childhood. Further, as children spend most of their daily time at school, where healthy behaviours are learned ${ }^{10}$, the school environment may promote healthy habits that positively affect children's weight status ${ }^{11}$. Thus, the aim of this study was to examine potential individual (demographic and behavioral), family and home, and school environmental correlates of BF and WC in children aged 9-11 years from São Caetano do Sul, Brazil.

\section{Methods}

\section{Data source}

The International Study of Childhood Obesity, Lifestyle and the Environment (ISCOLE) aimed to determine the relationships between lifestyle behaviours and obesity in a multi-national, cross-sectional sample of 9-11 year-old children $^{12}$. Data collection for this study was conducted in the Brazilian city of São Caetano do Sul.

A complete list of public and private schools enrolling $5^{\text {th }}$ grade students in São Caetano do Sul was assembled. Public and private schools were sampled separately and schools were selected from each list at a ratio of 4 (public) to 1 (private). All schools were placed in random order within each stratum and each school was approached according to the established order. This $80 \%$ public to $20 \%$ private schools ratio was purposely implemented to maximize socioeconomic status (SES) distribution. In total, 20 schools (16 public) were sampled in order to generate a sample of 25-30 children from each school with a stipulation that each sex comprise approximately $50 \%$ of the selected sample, resulting in a minimum enrollment of $5005^{\text {th }}$ grade children. Additional details on study design, sample size, and full methodology have been published elsewhere ${ }^{12}$. This project was approved by the research ethics board at the Federal University of São Paulo, Brazil and the participating school boards. Written informed parental consent and child assent were obtained for all participants.

\section{Anthropometric variables}

Data were collected by trained ISCOLE data collectors during an in-school visit according to standardized procedures ${ }^{12}$. Anthropometric variables included body height, body weight, body mass index (BMI), body fat percentage (BF\%), and WC. Body height $(\mathrm{cm})$ was measured without shoes using a Seca 213 portable stadiometer (Hamburg, Germany), with the head in the Frankfort plane. Body weight and BF\% were measured using a portable Tanita SC-240 body composition analyzer (Arlington Heights, IL, United States) after all outer clothing, heavy pocket items and shoes and socks were removed $^{13}$. WC measurements were made on exposed skin at the end of a normal expiration using a non-elastic anthropometric tape midway between the lower rib margin and the iliac crest ${ }^{12}$. 
Each measurement was repeated and the average was used for analysis (a third measurement was obtained if the first two measurements were $>0.5$ $\mathrm{cm}$ apart for body height and WC, $0.5 \mathrm{~kg}$ apart for body weight and $2.0 \%$ for $\mathrm{BF} \%$, respectively). The mean value of the two closest measurements was used for analysis.

\section{Potential correlates}

Demographic correlates. Parents were asked about the child's age, sex and ethnicity (white/ caucasian, black, mixed, other) in the ISCOLE Demographic and Family History Questionnaire.

Behavioral correlates. Participants completed the ISCOLE Diet and Lifestyle Questionnaire, containing questions asked to the child related to dietary intake, physical activity and sedentary behaviors ${ }^{12}$. Children completed a Food Frequency Questionnaire (FFQ) which asked how often participants consumed 23 food and beverage items in a usual consumption ${ }^{12}$. In the present paper, we use standardized principal component scores for these two patterns as the dependent variables "unhealthy diet pattern" (characterized by high intakes of fast foods, and fried food) and "healthy diet pattern" (including fruits and vegetables).

Children reported the frequency of breakfast consumption. Subsequently, weekly breakfast frequency (0-7 days per week) was calculated as the sum of weekday and weekend day breakfast frequency. Children were asked how many hours they typically watched television (TV) and played video game and/or computer per week day, and per weekend day ${ }^{12}$. Children were asked how many hours they typically watched TV, and how many hours they played video games and/ or used computer on weekdays and on weekends days separately ${ }^{12}$. For analysis, this is presented as a screen time score. Children were asked how they traveled (e.g., walking, car), to school most days and these responses were re-coded as active or inactive transport. Children also reported the time that it usually took them to travel to school.

Children were asked to wear an ActiGraph GT3X+ accelerometer (ActiGraph LLC, Pensacola) at the waist on an elasticized belt, and positioned in line with the right mid-axillary line, for at least 7 consecutive days (plus an initial familiarization day and the morning of the final day). Children were asked to wear the accelerometer 24h/day (removing only for water-related activities). Children received instruction during the initial in-school assessment on how to wear the accelerometer.
Data reduction strategies limited the analytical dataset to participants who provided at least four days of valid measurements (including at least one weekend day), with at least 10 hours/ day of waking wear time ${ }^{14}$. Data were collected at a sampling frequency of $80 \mathrm{~Hz}$, and subsequently downloaded in 1-second epochs, and aggregated to 15-second epochs for analysis using ActiLife Software (version 6, Actigraph LLC) ${ }^{15}$. Time spent in moderate-to-vigorous physical activity (MVPA) and sedentary behavior (SB) were estimated using the Evenson et al. ${ }^{15}$ cut points. To determine MVPA and SB, total sleep period time and non-wear time were identified using validated procedures ${ }^{16}$.

Family and home environment correlates. A Demographic and Family History Questionnaire, and a Neighborhood and Home Environment Questionnaire contained questions for parents related to their home and neighborhood environment. Parents were also asked about the child's age, sex, number of siblings birth country, health history of the child, total annual household income, parental education level, parental employment status, and number of working motorized vehicles at the household. Combined parental education level (highest level of either parent) was used by considering both parents' responses. Many questions were asked separately about both maternal and paternal parents, but the identity of the familial relationship of the individual completing the questionnaire (mother or father) was not captured by the questionnaire.

School environment correlates. An ISCOLE School Environment Questionnaire captured information on school characteristics, policies, and practices that may influence healthy eating and activity behaviours of the children. This questionnaire was completed by a school administrator or teacher in each of the participating schools. Lastly, one school audit was completed for each participating school by the research study team. This questionnaire recorded directly observed information on the school's built and food environments. Full details of the questionnaires are provided in Katzmarzyk et al. ${ }^{12}$.

Ferrari et al. ${ }^{17}$ provides additional details on response categories and additional details on measurement and analysis of potential individual, family and home, and school environmental correlates of BF and WC. Additional details on analytical sample, complete data, missing data study design, participating countries, and full methodology can be found in Ferrari et al. ${ }^{17}$. 


\section{Statistical analysis}

Male and female samples were described separately using the mean and standard deviation, or frequencies, depending on the nature of the variables. For the comparison between the two groups, the Student T Test, the Chi-Square Test for independence, and Standardized Adjusted Residuals were used. The normality of the data was assessed with the Kolmogorov-Smirnov Test.

We used multilevel linear regression models, including school in the second level (random intercept), to examine the associations of potential correlates with $\mathrm{BF} \%$ and WC. Due to the non-normal distribution, both variables were log-transformed for analysis and treated as continuous variables.

At first, univariate models, adjusted for age and ethnicity, with school as a random effect, were carried out for all potential correlates, separately in the boys and girls. The variables that were significant at $p<0.10$ in the univariate models, were included in multiple models (also adjusted for age and ethnicity, with school as a random effect) to determine the correlates of BF\% and WC, among boys and among girls. Variables that were significant at $\mathrm{p}<0.10$ in the multiple models were considered correlates of BF and WC. Data were analyzed using Statistical Package for the Social Sciences (SPSS) software, version 22.0.

\section{Results}

Complete data for the outcomes of interest and all investigated correlates were available for 328 children. Missing data were found for 256 participants of the original sample of participants ${ }^{17}$.

Characteristics of participating children and their parents are summarized in Table 1. The sample included 328 children aged from 9 to 11 years old $(\mathrm{M}=10.4 ; \mathrm{SD}=0.5)$, and $169(51.5 \%)$ were boys. The majority (75.9\%) was white/caucasian ( $73.4 \%$ of the boys and $78.6 \%$ of the girls). The comparison between boys and girls showed significant higher percentage of BF among girls $(\mathrm{p}<0.001)$, but no significant differences with respect to WC, height, weight, or BMI ( $\mathrm{p}>0.05)$. However, the percentage of overweight was higher among girls ( $30.8 \%$ vs. $17.2 \%)$, and the percentage obese was higher among boys $(33.1 \%$ vs. $22.6 \%)$.

Boys had a higher healthy diet score $(\mathrm{p}=0.024)$ and ate breakfast more often than girls $(\mathrm{p}=0.042)$. They also had higher screen time ( $\mathrm{p}=0.053)$, which is explained by more time spent playing videogames/computer $(\mathrm{p}=0.007)$, since there were no differences between boys and girls in TV time ( $\mathrm{p}=0.616)$ (Table 1).

More than half of boys and girls spent less than 15 minutes to travel to school and did it in an inactive mode. More than $90 \%$ of boys and of girls classified their sleep quality and quantity as very good/fairly good. There were no significant differences between boys and girls with respect to these variables $(\mathrm{p}>0.05)$ (Table 1$)$.

Mean MVPA time was $71.2 \mathrm{~min} /$ day for boys and $46.6 \mathrm{~min} /$ day for girls $(\mathrm{p}<0.001)$. More than half of boys $(63.9 \%)$ met MVPA guidelines. Among girls, only 25.1\% met MVPA guidelines ${ }^{18}$. On the other hand, SB was higher among girls than among boys $(\mathrm{p}=0.005)$ (Table 1$)$.

There were no significant differences between boys and girls with respect to the family, home and school environment characteristics ( $\mathrm{p}>0.05)$ (Table 1). On average, each family had $2.3 \mathrm{TVs}$ at home and more than $70 \%$ of children have a TV in the bedroom. More than half of the parents have completed high school or some college. About half of the mothers and two-thirds of the fathers work full time.

Results from the multiple models (Table 2) showed that, among boys, breakfast consumption and MVPA were negatively associated with $\mathrm{BF} \%$. Sleep quality was positively associated with $\mathrm{BF} \%$. Sedentary behavior and TV in bedroom were not associated with $\mathrm{BF} \%$.

Among girls, the only variable negatively associated with $\mathrm{BF} \%$ was the breakfast consumption. Sleep quantity was positively associated with BF\%. Time to travel to school was not associated with BF\% (Table 2).

Results from the multiple models for WC (Table 3) showed a positive association of sleep quality with WC in boys. MVPA was negatively associated with WC. Screen time, TV in bedroom and policies or practices oh healthy eating were not associated with WC.

Among girls, WC was negatively associated with breakfast consumption. Sleep quantity was positively associated with WC.

\section{Discussion}

The aim of this study was to examine potential correlates of BF and WC in Brazilian children. In boys, breakfast consumption, bad sleep quality, and MVPA were associated with $\mathrm{BF} \%$. Among girls, the only variables associated with $\mathrm{BF} \%$ were 
Table 1. Demographic, anthropometric, behavioral, family, home and school environment characteristics in children from São Caetano do Sul, Brazil by sex.

\begin{tabular}{|c|c|c|c|}
\hline Variables & Boys $(n=169)$ & Girls $(n=159)$ & p-value \\
\hline \multicolumn{4}{|l|}{ Demographic } \\
\hline Age (years) & $10.4(0.5)$ & $10.4(0.5)$ & $0.844^{(1)}$ \\
\hline Ethnicity & & & $0.091^{(2)}$ \\
\hline White/Caucasian & $124(73.4 \%)$ & $125(78.6 \%)$ & \\
\hline Black & $13(7.7 \%)$ & $11(6.9 \%)$ & \\
\hline Mixed & $28(16.6 \%)$ & $14(8.8 \%)$ & \\
\hline Other & $4(2.4 \%)$ & $9(5.7 \%)$ & \\
\hline \multicolumn{4}{|l|}{ Anthropometric } \\
\hline Body fat percentage (\%) & $21.3(9.6)$ & $25.8(9.0)$ & $<0.001^{(1)}$ \\
\hline Waist circumference $(\mathrm{cm})$ & $68.0(11.7)$ & $67.2(9.8)$ & $0.544^{(1)}$ \\
\hline Height $(\mathrm{cm})$ & $143.3(7.1)$ & $144.4(8.2)$ & $0.187^{(1)}$ \\
\hline Weight (kg) & $41.7(12.9)$ & $42.6(12.2)$ & $0.528^{(1)}$ \\
\hline Body mass index (BMI) $\left(\mathrm{kg} / \mathrm{m}^{2}\right)$ & $20.1(4.7)$ & $20.2(4.5)$ & $0.713^{(1)}$ \\
\hline BMI weight status ${ }^{19}$ & & & $0.014^{(2)}$ \\
\hline Underweight & $3(1.8 \%)$ & $1(0.6 \%)$ & \\
\hline Normal weight & $81(47.9 \%)$ & $73(45.9 \%)$ & \\
\hline Overweight & $29(17.2 \%)^{(-)}$ & $49(30.8 \%)^{(+)}$ & \\
\hline Obese & $56(33.1 \%)^{(+)}$ & $36(22.6 \%)^{(-)}$ & \\
\hline \multicolumn{4}{|l|}{ Behavioral } \\
\hline Unhealthy diet score & $0.021(1.025)$ & $-0.022(0.976)$ & $0.697^{(1)}$ \\
\hline Healthy diet score & $0.120(1.087)$ & $-0.128(0.883)$ & $0.024^{(1)}$ \\
\hline Breakfast consumption (days/week) & $5.4(2.1)$ & $4.9(2.2)$ & $0.042^{(1)}$ \\
\hline \multicolumn{4}{|l|}{ Screen time score (hour/day) } \\
\hline Total screen time & $4.1(2.2)$ & $3.7(2.1)$ & $0.053^{(1)}$ \\
\hline TV & $2.3(1.4)$ & $2.3(1.3)$ & $0.616^{(1)}$ \\
\hline Video game/computer & $1.8(1.3)$ & $1.4(1.2)$ & $0.007^{(1)}$ \\
\hline Travel mode to school & & & $0.566^{(2)}$ \\
\hline Active & $67(39.6 \%)$ & $68(42.8 \%)$ & \\
\hline Inactive & $102(60.4 \%)$ & $91(57.2 \%)$ & \\
\hline Time to school & & & $0.054^{(2)}$ \\
\hline$\leq 15$ minutes & $102(60.4 \%)$ & $116(73.0 \%)$ & \\
\hline$>15-<30$ minutes & $39(23.1 \%)$ & $25(15.7 \%)$ & \\
\hline$>30$ minutes & $28(16.6 \%)$ & $18(11.3 \%)$ & \\
\hline Sleep quality & & & $0.361^{(2)}$ \\
\hline Fairly bad, very bad & $6(3.6 \%)$ & $9(5.7 \%)$ & \\
\hline Very good, fairly good & $163(96.4 \%)$ & $150(94.3 \%)$ & \\
\hline Sleep quantity & & & $0.698^{(2)}$ \\
\hline Fairly bad, very bad & $9(5.3 \%)$ & $7(4.4 \%)$ & \\
\hline Very good, fairly good & $160(94.7 \%)$ & $152(95.6 \%)$ & \\
\hline Physical education classes & & & $0.715^{(2)}$ \\
\hline$\leq 2$ days & $141(83.4 \%)$ & $135(84.9 \%)$ & \\
\hline$\geq 3$ days & $28(16.6 \%)$ & $24(15.1 \%)$ & \\
\hline Mean (SD) & $2.1(1.1)$ & $2.1(0.9)$ & $0.400^{(1)}$ \\
\hline \multicolumn{4}{|l|}{ Physical activity (min/day) } \\
\hline MVPA & $71.2(27.0)$ & $46.6(18.6)$ & $<0.001^{(1)}$ \\
\hline MPA & $48.4(16.5)$ & $34.0(12.9)$ & $<0.001^{(1)}$ \\
\hline VPA & $22.8(12.7)$ & $12.6(6.8)$ & $<0.001^{(1)}$ \\
\hline Meeting MVPA guidelines $(\geq 60 \mathrm{~min} / \text { day })^{18}$ & $108(63.9 \%)$ & $40(25.1 \%)$ & $<0.001^{(2)}$ \\
\hline Sedentary behaviour (min/day) & $489.7(69.2)$ & $511.1(67.3)$ & 0.005 \\
\hline
\end{tabular}


Table 1. Demographic, anthropometric, behavioral, family, home and school environment characteristics in children from São Caetano do Sul, Brazil by sex.

\begin{tabular}{|c|c|c|c|}
\hline Variables & Boys $(n=169)$ & Girls $(n=159)$ & p-value \\
\hline \multicolumn{4}{|l|}{ Family and home environment } \\
\hline Siblings & $1.3(1.1)$ & $1.3(1.1)$ & $0.979^{(1)}$ \\
\hline $\begin{array}{l}\text { Total annual household income (Brazilian } \\
\text { Real) }\end{array}$ & & & $0.099^{(2)}$ \\
\hline Less than $\mathrm{R} \$ 19,620$ & $59(34.9 \%)$ & $57(35.8 \%)$ & \\
\hline $\mathrm{R} \$ 19,621$ to $<32,700$ & $54(32.0 \%)$ & $33(20.8 \%)$ & \\
\hline $\mathrm{R} \$ 32,701$ to 58,860 & $35(20.7 \%)$ & $41(25.8 \%)$ & \\
\hline $\mathrm{R} \$ 58,861$ and above & $21(12.4 \%)$ & $28(17.6 \%)$ & \\
\hline TVs in home & $2.3(1.0)$ & $2.3(0.9)$ & $0.558^{(1)}$ \\
\hline TV in bedroom & & & $0.663^{(2)}$ \\
\hline Yes & $124(73.4 \%)$ & $120(75.5 \%)$ & \\
\hline No & $45(26.6 \%)$ & $39(24.5 \%)$ & \\
\hline Automobiles & $1.0(0.8)$ & $1.0(0.8)$ & $0.628^{(1)}$ \\
\hline Combined parental educational level & & & $0.970^{(2)}$ \\
\hline Did not complete high school & $38(22.5 \%)$ & $34(21.4 \%)$ & \\
\hline Completed high school or some college & $94(55.6 \%)$ & $90(56.6 \%)$ & \\
\hline $\begin{array}{l}\text { Completed bachelor or postgraduate } \\
\text { degree }\end{array}$ & $37(21.9 \%)$ & $35(22.0 \%)$ & \\
\hline \multicolumn{4}{|l|}{ Maternal characteristics } \\
\hline Employment status & & & $0.190^{(2)}$ \\
\hline Part-time or less & $93(55.0 \%)$ & $76(47.8 \%)$ & \\
\hline Full-time & $76(45.0 \%)$ & $83(52.2 \%)$ & \\
\hline \multicolumn{4}{|l|}{ Paternal characteristics } \\
\hline Employment status & & & $0.964^{(2)}$ \\
\hline Part-time or less & $57(33.7 \%)$ & $54(34.0 \%)$ & \\
\hline Full-time & $112(66.3 \%)$ & $105(66.0 \%)$ & \\
\hline \multicolumn{4}{|l|}{ School environment } \\
\hline Type of school & & & $0.667^{(2)}$ \\
\hline Public school & $165(97.6 \%)$ & $154(96.9 \%)$ & \\
\hline Private school & $4(2.4 \%)$ & $5(3.1 \%)$ & \\
\hline $\begin{array}{l}\text { Children in schools that has in practice } \\
\text { policies about physical activity }\end{array}$ & $82(48.5 \%)$ & $94(59.1 \%)$ & $0.054^{(2)}$ \\
\hline $\begin{array}{l}\text { Children in schools that has in practice } \\
\text { policies about healthy eating }\end{array}$ & $71(42.0 \%)$ & $76(47.8 \%)$ & $0.292^{(2)}$ \\
\hline
\end{tabular}

breakfast consumption and a bad sleep quantity. Bad sleep quality and MVPA were associated with WC in boys. Among girls, WC was associated with breakfast consumption and bad sleep quantity. Correlates identified here are similar to those identified in previous studies ${ }^{20,21}$.

There is a clear link between intra-abdominal fat and metabolic abnormalities, such as plasma cholesterol, triglyceride, insulin concentrations ${ }^{22}$ and cardiovascular risk factors in children ${ }^{6}$. In adults, central (intra-abdominal) distribution of BF increases risk of the metabolic syndrome more than peripheral distribution ${ }^{5}$ and it is well established that a more central fat distribution is associated with an increased risk of ill health ${ }^{23}$. WC measurements have been used to estimate intra-abdominal fat in children ${ }^{24}$. Pediatric studies consistently show strong correlations of WC with components of the metabolic syndrome, including dyslipidemia and fasting insulin ${ }^{22}$. Studies in children have also showed that a greater deposition of central fat is correlated with less fa- 
Table 2. Final multiple models for correlates with the logarithm of body fat percentage in in children from São Caetano do Sul, Brazil ${ }^{\text {a }}$

\begin{tabular}{|c|c|c|c|c|}
\hline \multirow{2}{*}{ Variables } & \multicolumn{2}{|l|}{ Boys $(n=169)$} & \multicolumn{2}{|l|}{ Girls $(n=159)$} \\
\hline & $\beta$ coefficient $(95 \% \mathrm{CI})$ & p-value & $\beta$ coefficient $(95 \% \mathrm{CI})$ & p-value \\
\hline \multicolumn{5}{|l|}{ Behavioral correlates } \\
\hline Breakfast consumption (days/week) & $-0.0131(-0.027,0.001)$ & 0.065 & $-0.0107(-0.023,0.001)$ & 0.075 \\
\hline $\begin{array}{l}\text { Time of travel to school }(>15-<30 \\
\text { min) }\end{array}$ & - & & $0.0472(-0.034,0.128)$ & 0.250 \\
\hline Time of travel to school ( $\geq 30 \mathrm{~min})$ & - & & $-0.0066(-0.106,0.093)$ & 0.897 \\
\hline Sleep quality (fairly bad, very bad) & $0.1356(-0.012,0.283)$ & 0.071 & - & \\
\hline Sleep quantity (fairly bad, very bad) & - & & $0.1179(-0.006,0.241)$ & 0.061 \\
\hline Physical education classes & - & & - & \\
\hline MVPA (minutes) & $-0.0023(-0.004,-0.001)$ & $<0.001$ & - & \\
\hline Sedentary behavior (minutes) & $-0.0001(-0.0005,0.0004)$ & 0.826 & & \\
\hline \multicolumn{5}{|l|}{$\begin{array}{l}\text { Family and home environment } \\
\text { correlates }\end{array}$} \\
\hline TV in bedroom (yes) & $0.0415(-0.022,0.105)$ & 0.199 & - & \\
\hline $\begin{array}{l}\text { a Multilevel linear regression model including } \\
\text { school as a random effect }\left(2^{\text {nd }} \text { level); unstanda }\right. \\
\text { Independent variables with p-value }<0.10 \text { in th } \\
\text { Reference categories in categorical variables: ti } \\
\text { good; TV in bedroom: no. }\end{array}$ & $\begin{array}{l}\text { significant variables from the } \mathrm{f} \\
\text { ized beta coefficients are presen } \\
\text { univariate models (Table 4); } \\
\text { e of travel to school: } \leq 15 \mathrm{~min} \text {; }\end{array}$ & $\begin{array}{l}11 \text { model, } \\
\text { ed; } 95 \% \mathrm{C}\end{array}$ & $\begin{array}{l}\text { ontrolling for ethnicity and } \\
\text { 95\% confidence intervals; } \\
\text { and sleep quantity: very goo }\end{array}$ & d, fairly \\
\hline
\end{tabular}

Table 3. Final multiple model for correlates with the logarithm of waist circumference in children from São Caetano do Sul, Brazil. ${ }^{a}$

\begin{tabular}{|c|c|c|c|c|}
\hline \multirow{2}{*}{ Variables } & \multicolumn{2}{|l|}{ Boys $(n=169)$} & \multicolumn{2}{|l|}{ Girls $(n=159)$} \\
\hline & $\beta$ coefficient $(95 \% \mathrm{CI})$ & p-value & $\beta$ coefficient $(95 \% \mathrm{CI})$ & p-value \\
\hline \multicolumn{5}{|l|}{ Behavioral correlates } \\
\hline Breakfast consumption (days/week) & - & & $-0.0123(-0.024,-0.001)$ & 0.039 \\
\hline Screen time - Video (hour/day) & $0.0134(-0.008,0.035)$ & 0.211 & - & \\
\hline Sleep quality (fairly bad, very bad) & $0.1310(-0.017,0.279)$ & 0.082 & - & \\
\hline Sleep quantity (fairly bad, very bad) & - & & $0.1178(-0.005,0.240)$ & 0.059 \\
\hline MVPA (minutes) & $-0.0021(-0.003,-0.001)$ & $<0.001$ & - & \\
\hline \multicolumn{5}{|c|}{ Family and home environment correlates } \\
\hline TV in bedroom (yes) & $0.0420(-0.022,0.106)$ & 0.194 & - & \\
\hline \multicolumn{5}{|l|}{ School environment correlates } \\
\hline $\begin{array}{l}\text { Policies or practices on healthy eating } \\
\text { (no) }\end{array}$ & $-0.0460(-0.128,0.035)$ & 0.252 & - & \\
\hline $\begin{array}{l}{ }^{a} \text { Multilevel linear regression model including all } \\
\text { school as a random effect ( } 2^{\text {nd }} \text { level): unstandard } \\
\text { Independent variables with p-value }<0.10 \text { in the } \\
\text { Reference categories in categorical variables: slee }\end{array}$ & $\begin{array}{l}\text { significant variables from the } \\
\text { zed beta coefficients are prese } \\
\text { univariate models (Table 6); } \\
\text { quality and sleep quantity: } v\end{array}$ & $\begin{array}{l}\text { all model, } \\
\text { ted; } 95 \% C\end{array}$ & $\begin{array}{l}\text { controlling for ethnicity and a } \\
\text { I: } 95 \% \text { confidence intervals; } \\
\text { irly good; TV in bedroom: no }\end{array}$ & $\begin{array}{l}\text { ge, with } \\
\text {; policies }\end{array}$ \\
\hline
\end{tabular}

vorable patterns of serum lipoprotein concentrations and blood pressure ${ }^{25}$. Because adiposity and cardiovascular risk factors track from childhood into adulthood, early identification of children with high central adiposity is important.

These results have implications for the diagnosis of obesity-related health concerns among children, as well as the assessment of total and regional adiposity in growth studies. For example, WC is a common component of clinical definitions of metabolic syndrome in children ${ }^{23}$. Within the context of metabolic syndrome, WC is primarily viewed as a marker of "abdominal" obesity, as generalized obesity has not typically 
been considered as an important component of the syndrome. Some information exists on the stability and tracking of abdominal fat distribution and it indicates rather moderate tracking, especially for indices describing subcutaneous adipose tissue.

We found that MVPA is a correlate of adiposity. Systematic reviews have concluded that higher levels of objectively measured physical activity are associated with lower levels of body fatness in children and adolescents ${ }^{20}$. More recent evidence from studies using objective measures of physical activity is supportive of the conclusion that higher levels of physical activity are associated with lower adiposity ${ }^{26}$. Steele et al. ${ }^{26}$ reported negative associations between bioelectrical impedance determined body composition variables with time spent in accelerometer-determined MVPA (defined as $>2000$ counts $/ \mathrm{min}$ ). In contrast to our study, however, their definition of MVPA (defined as $>2000$ counts/min) differed from our own both in magnitude and epoch time length $(\geq 574$ counts $/ 15 \mathrm{sec})$. The magnitude of the associations was strongest as what we observed ( = -0.044 versus $=-0.0021$ for WC and MVPA). $\mathrm{A}$ recent systematic review concluded that physical activity was associated more consistently with adiposity in boys than girls ${ }^{20}$, and the present study was consistent with this finding. It is not clear why adiposity development might be more sensitive to variation in physical activity in boys than in girls, but it is possible that influences on the energy-intake side of the energy-balance equation may be more important in girls than boys. In particular, low physical activity is considered in children as significant correlates of excess body fat ${ }^{17}$.

The relationship between dietary patterns and childhood overweight and obesity is still unclear in the literature ${ }^{27}$. Children with overweight problems have been reported to be more likely to skip breakfast ${ }^{27}$. The sample in the present study reported consuming breakfast with $57 \%$ being categorized as frequent (6-7 days/week), 25.6\% occasional (3-5 days/week) and $17.4 \%$ rare (0-2 days/week) breakfast consumers. These values are consistent with previous reviews reporting that $10-30 \%$ of young people in Europe and the United States regularly skip breakfast. Consistent with past work ${ }^{21}$, we showed an inverse association between breakfast frequency and adiposity indicators (BF and WC). Furthermore, our analyses showed these associations to be independent of ethnicity and age with school as a random effect. Zakrzewski et al. ${ }^{27}$ analyzed data from chil- dren from 12 countries in ISCOLE and showed that frequent breakfast consumption (6-7 days/ week) was associated with lower BMI and BF\% compared with both occasional (3-5 days/week) and rare (0-2 days/week) consumption independent of age, sex and parental education. However, relationships were not consistently observed across the 12 study sites; some countries showed no association (Australia, Finland and Kenya), and others showed that occasional, but not rare, consumption was associated with higher BMI $\mathrm{z}$-scores compared with frequent consumption (Canada, Portugal and South Africa). The role of dietary patterns with respect to the risk of overweight and obesity in children and the interaction with other variables (e.g., physical activity) needs to be determined in future studies.

Previous studies have found significant associations between short sleep duration and obesity in children ${ }^{28}$. A meta-analysis among children showed an odds ratio for overweight and obesity of 0.91 (95\% CI: $0.84-1.00)$ per each additional hour of sleep duration ${ }^{28}$. However, all of the studies in this review were from high and upper-middle income countries. Katzmarzyk et al. ${ }^{29}$ presented mean BMI $z$-scores across quintiles of sleep duration. The authors found the significant linear trends across quintiles of nocturnal sleep duration $(\mathrm{p}<0.01$; negative) in both boys and girls from ISCOLE ${ }^{29}$. In our data, the results demonstrated a significant negative association between self-reported sleep quantity and quality and obesity. Brazilian researchers ${ }^{30}$ have reported significant associations between short sleep duration and obesity among adolescents. The authors showed that each hour of sleep was associated with an odds ratio of obesity of $0.70(95 \%$ CI: 0.49-0.99) $)^{30}$.

Especially in children, prevention is universally seen as the best approach to reverse the increasing global prevalence of overweight/obesity ${ }^{3}$. Despite the apparent fascination of prevention, to date, there is limited evidence on the most effective means of preventing childhood obesity. This may be partly related to the relatively small sample sizes for the expected effect size and/or insufficient duration of the longitudinal study in many prevention trials. Prevention is multi-level and measures should be instituted at the individual, family, community, and institutional healthcare levels ${ }^{3}$.

This study has several strengths and limitations. The limitations include the cross-sectional design, and not being representative of the population. The work presented was restricted 
to children 9 to 11 years of age and, therefore, limits the generalizability to other age groups and we did not assess of pubertal development. Nevertheless, this study provides robust objective measures of several healthy active living variables and related correlates among a large group of Brazilian school children and represents the first study of this kind in Brazil. The limitations of accelerometry should also be considered. However, objective measurement of PA reduces the error and bias commonly associated with self-reported measures. This is one of only a few studies to identify correlates of BF and $\mathrm{WC}$ among children in a middle income country, and the first to examine this issue in a sample of Brazilian children.

\section{Conclusion}

The current study has shown evidence of significant correlates of BF and WC in children. However, few correlates were common for both $\mathrm{BF}$ and WC, and for both boys and girls.
In boys, breakfast consumption, bad sleep quality, and MVPA were associated with BF. Among girls, the only variables associated with BF were breakfast consumption and bad sleep quantity. Bad sleep quality and MVPA were associated with WC in boys. Among girls, WC was associated with breakfast consumption and bad sleep quantity.

Some of significant correlates are modifiable (i.e., physical activity), and require more intense behavioral interventions. The results of this study support the idea that a single strategy to reduce BF and WC is unlikely to be effective; however, a strategy aimed at similar behaviours (i.e., correlates identified), is possible. Future work should adapt these findings to provide meaningful public health strategies and messages and test these correlates in a intervention to reduce $\mathrm{BF}$ and $\mathrm{WC}$ in children. This may help to improve lifestyle behaviors such as physical activity, reduce excessive time spent in SB and screen time, and ultimately reduce the risk of preventable chronic diseases such as obesity.

\section{Collaborators}

All authors have sufficiently contributed to the development of this study.

\section{Acknowledgments}

The authors thank the participants, their parents and guardians, the teachers and coordinators of Municipal Secretary Education of São Caetano do Sul and the Municipal Government of São Caetano do Sul.

ISCOLE was funded by The Coca-Cola Company. The funder had no role in study design, data collection and analysis, decision to publish, or preparation of the manuscript. 


\section{References}

1. World Health Organization (WHO). Obesity: preventing and managing the global epidemic. WHO: Geneva; 2000.

2. Wu JF. Childhood obesity: a growing global health hazard extending to adulthood. Pediatr Neonatol 2013;54(2):71-72.

3. Ng M, Fleming T, Robinson M, Thomson B, Graetz N, Margono C, Mullamy E, Biryukov S, Abbafati C, Abera SF, Abraham JP, Abu-Rmeileh NME, Achoki T, AlBuhairan FS, Alemu ZA, Alfonso R, Ali MK, Ali R, Guzman NA, Ammar W, Anwari P, Banerjee A, Barquera S, Basu S, Bennett DA, Bhutta Z, Blore J, Cabral N, Nonato IC, Chang JC, Chowdhury R, Courville KJ, Criqui MH, Cundiff DK, Dabhadkar KC, Dandona L, Davis A, Dayama A, Dharmaratne SD, Ding EL, Durrani AM, Esteghamati A, Farzadfar F, Fay DF, Feigin VL, Flaxman A, Forouzanfar MH, Goto A, Green MA, Gupta R, Hafezi-Nejad N, Hankey GJ, Harewood HC, Havmoeller R, Hay S, Hernandez L, Husseini A, Idrisov BT, Ikeda N, Islami F, Jahangir E, Jassal SK, Jee SH, Jeffreys M, Jonas JB, Kabagambe EK, Khalifa SE, Kengne AP, Khader YS, Khang YH, Kim D, Kimokoti RW, Kinge JM, Kokubo Y, Kosen S, Kwan G, Lai T, Leinsalu M, Li Y, Liang X, Liu S, Logroscino G, Lotufo PA, Lu Y, Ma J, Mainoo NK, Mensah GA, Merriman TR, Mokdad AH, Moschandreas J, Naghavi M, Naheed A, Nand D, Narayan KM, Nelson EL, Neuhouser ML, Nisar MI, Ohkubo T, Oti SO, Pedroza A, Prabhakaran D, Roy N, Sampson U, Seo H, Sepanlou SG, Shibuya K, Shiri R, Shiue I, Singh GM, Singh JA, Skirbekk V, Stapelberg NJ, Sturua L, Sykes BL, Tobias M, Tran BX, Trasande L, Toyoshima H, van de Vijver S, Vasankari TJ, Veerman JL, VelasquezMelendez G, Vlassov VV, Vollset SE, Vos T, Wang C, Wang X, Weiderpass E, Werdecker A, Wright JL, Yang YC, Yatsuya H, Yoon J, Yoon SJ, Zhao Y, Zhou M, Zhu S, Lopez AD, Murray CJ, Gakidou E. Global, regional, and national prevalence of overweight and obesity in children and adults during 1980-2013: a systematic analysis for the Global Burden of Disease Study 2013. Lancet 2014;384(9945):766-781.

4. Tchernof A, Despres JP. Pathophysiology of human visceral obesity: an update. Physiol Rev 2013;93(1):359-404.

5. Pouliot MC, Despres JP, Lemieux S, Moorjani S, Bouchard C, Tremblat A, Nadeau A, Lupien PJ. Waist circumference and abdominal sagittal diameter: best simple anthropometric indexes of abdominal visceral adipose tissue accumulation and related cardiovascular risk in men and women. Am J Cardiol 1994;73(7):460-468.

6. Savva SC, Tornaritis M, Savva ME, Kourides Y, Panagi A, Silikiotou N, Georgiou C, Kafatos A. Waist circumference and waist-to-height ratio are better predictors of cardiovascular disease risk factors in children than body mass index. Int J Obes Relat Metab Disord 2000;24(11):1453-1458.

7. Instituto Brasileiro de Geografia e Estatística (IBGE). Pesquisa de Orçamentos Familiares (POF) 2008-2009: Antropometria e estado nutricional de crianças, adolescentes e adultos no Brasil. Rio de Janeiro: IBGE; 2010.
8. Lavelle HV, Mackay DF, Pell JP. Systematic review and meta-analysis of school-based interventions to reduce body mass index. J Public Health 2012;34(3):360-369.

9. Guerra PH, Nobre MR, Silveira JA, Taddei JA. The effect of school-based physical activity interventions on body mass index: a meta-analysis of randomized trials. Clinics 2013;68(9):1263-1273.

10. Llargues E, Franco R, Recasens A, Nadal A, Vila M, Pérez MJ, Manresa JM, Recasens I, Salvador G, Serra J, Roure E, Castells C. Assessment of a school-based intervention in eating habits and physical activity in school children: the AVall study. J Epidemiol Community Health 2011;65(10):896-901.

11. Story M, Nanney MS, Schwartz MB. Schools and obesity prevention: creating school environments and policies to promote healthy eating and physical activity. Milbank Q 2009;87(1):71-100.

12. Katzmarzyk PT, Barreira TV, Broyles ST, Champagne CM, Chaput JP, Fogelholm M, Hu G, Johnson WD, Kuriyan R, Kurpad A, Lambert EV, Maher C, Maia J, Matsudo V, Olds T, Onywera V, Sarmiento OL, Standage M, Tremblay MS, Tudor-Locke C, Zhao P, Church TS. The International Study of Childhood Obesity, Lifestyle and the Environment (ISCOLE): design and methods. BMC Public Health 2013;13:900.

13. Barreira TV, Staiano AE, Katzmarzyk PT. Validity assessment of a portable bioimpedance scale to estimate body fat percentage in white and African-American children and adolescents. Pediatr Obes 2013;8(2):2932.

14. Trost SG, Loprinzi PD, Moore R, Pfeiffer KA. Comparison of accelerometer cut points for predicting activity intensity in youth. Med Sci Sports Exerc 2011;43(7):1360-1368.

15. Evenson KR, Catellier DJ, Gill K, Ondrak KS, McMurray RG. Calibration of two objective measures of physical activity for children. J Sports Sci 2008;26(14):1557-1565.

16. Barreira TV, Schuna JM Jr., Mire EF, Katzmarzyk PT, Chaput JP, Leduc G, Tudor-Locke C. Identifying children's nocturnal sleep using 24-h waist accelerometry. Med Sci Sports Exerc 2015;47(5):937-943.

17. Ferrari GL, Matsudo V, Barreira TV, Tudor-Locke C, Katzmarzyk PT, Fisberg M. Correlates of Moderate-to-Vigorous Physical Activity in Brazilian Children. J Phys Act Health 2016;13(10):1132-1145.

18. World Health Organization (WHO). Global recommendations on physical activity for health. Geneva: WHO; 2010.

19. de Onis M, Onyango AW, Borghi E, Siyam A, Nishida C, Siekmann J. Development of a WHO growth reference for school-aged children and adolescents. Bull World Health Organ 2007;85(9):660-667.

20. Jimenez-Pavon D, Kelly J, Reilly JJ. Associations between objectively measured habitual physical activity and adiposity in children and adolescents: Systematic review. Int J Pediatric Obes 2010;5(1):3-18. 
21. Hallstrom L, Labayen I, Ruiz JR, Patterson E, Vereecken CA, Breidenassel C, Gottrand F, Huybrechts I, Manios Y, Mistura L, Widhalm K, Kondaki K, Moreno LA, Sjöström M, HELENA Study Group. Breakfast consumption and CVD risk factors in European adolescents: the HELENA (Healthy Lifestyle in Europe by Nutrition in Adolescence) Study. Public Health Nutr 2013;16(7):1296-1305.

22. Cowin I, Emmett P. Cholesterol and triglyceride concentrations, birthweight and central obesity in preschool children. ALSPAC Study Team. Avon Longitudinal Study of Pregnancy and Childhood. Int J Obes Relat Metab Disord 2000;24(3):330-339.

23. Ford ES, Li C. Defining the metabolic syndrome in children and adolescents: will the real definition please stand up?. J Pediatr 2008;152(2):160-164.

24. Goran MI, Gower BA. Relation between visceral fat and disease risk in children and adolescents. Am JClin Nutr 1999;70(1):149S-56S.

25. Lawlor DA, Benfield L, Logue J. Tilling K, Howe LD, Fraser A, Cherry L, Watt P, Ness AR, Davey Smith G, Sattar N. Association between general and central adiposity in childhood, and change in these, with cardiovascular risk factors in adolescence: prospective cohort study. BMJ 2010;341:c6224.

26. Steele RM, van Sluijs EM, Cassidy A, Griffin SJ, Ekelund U. Targeting sedentary time or moderateand vigorous-intensity activity: independent relations with adiposity in a population-based sample of 10-y-old British children. American J Clin Nutr 2009;90(5):1185-1192.

27. Zakrzewski JK, Gillison FB, Cumming S, Church TS, Katzmarzyk PT, Broyles ST, Champagne CM, Chaput JP, Denstel KD, Fogelholm M, Hu G, Kuriyan R, Kurpad A, Lambert EV, Maher C, Maia J, Matsudo V, Mire EF, Olds T, Onywera V, Sarmiento OL, Tremblay MS, Tudor-Locke C, Zhao P, Standage M, ISCOLE Research Group. Associations between breakfast frequency and adiposity indicators in children from 12 countries. Int J Obes Suppl 2015;5(Suppl 2):S80-88.

28. Chen X, Beydoun MA, Wang Y. Is sleep duration associated with childhood obesity? A systematic review and meta-analysis. Obesity 2008;16(2):265-274.

29. Katzmarzyk PT, Barreira TV, Broyles ST, Champagne CM, Chaput JP, Fogelholm M, Hu G, Johnson WD, Kuriyan R, Kurpad A, Lambert EV, Maher C, Maia J, Matsudo V, Olds T, Onywera V, Sarmiento OL, Standage M, Tremblay MS, Tudor-Locke C, Zhao P, Church TS, ISCOLE Research Group. Relationship between lifestyle behaviors and obesity in children ages 9-11: Results from a 12-country study. Obesity 2015;23(8):1696-1702.

30. Wells JC, Hallal PC, Reichert FF, Menezes AM, Araujo CL, Victora CG. Sleep patterns and television viewing in relation to obesity and blood pressure: evidence from an adolescent Brazilian birth cohort. Int J Obes 2008;32(7):1042-1049.

Artigo apresentado em 02/07/2017

Aprovado em 27/04/2018

Versão final apresentada em 29/04/2018 
